\title{
The Undocumented Benefits of Buildings
}

A friend sent, via computer, a photo of an Indian peddler in Bangalore carrying computer equipment in a hand-woven basket on his head. Whatever the photo says about the digital and economic divide in India, it also symbolizes a dilemma faced by every architect. We live in a time in which equipment, be it computers or the computer-controlled systems in buildings, have a greater perceived value than that which contains them, the largely hand-made structures that constitute architecture. Business investment in equipment has increased at the expense of investment in structures, even as the cost of equipment has decreased and that of buildings has increased. Architecture has become, like that peddler's basket, a necessary but under-valued aspect of daily life - and we, as a profession, seem ill-equipped to argue otherwise.

One response to this among architects has been to create buildings that perform - and sometimes look - like the machines they house. This has driven much of the funded research in our field, with its focus on the functional, operational, and technical performance of buildings, which has merit. But it is not the only response we might make.

Consider that peddler's basket. While primitive in some ways, it is more refined in other ways than the computer equipment it carries, having evolved over centuries into an extremely adaptable and durable form, using renewable resources. Vernacular buildings share these characteristics, although, like the basket, we often think of them as unsophisticated when compared to 'high' technology. In terms of investment, the life-cycle cost and financial return over time of vernacular structures is extraordinarily high and probably greater than our rapidly obsolescent machines and machine-like buildings. Likewise, older buildings often prove more adaptable to high-technology; witness the frequency with which up-start dot.com companies have gravitated to rehabilitated warehouses and lofts in the center of cities.

The reason for the relative decline in investment in buildings lies not with them, but with us. We need to continue to seek improvements in the performance of buildings, but we need to do a much better job demonstrating the value of architecture as something different from and yet as essential to the productivity of people as the computers on our desks. 


\section{architectural research quarterly}

\section{Subscribe now and save $20 \%$}

Innovative in conception, unique in breadth and generously illustrated, this pace-setring quarterly publication from Cambridge University Press links, on a global scale, the worlds of architectural practice and research. arq regularly includes extensive peer-reviewed sections on design, history, theory, construction, environmental design, information technology and practice - as well as structures, urbanism and documents. These are supplemented by letters, reports, reviews, a directory of specialist research centers and consultancies and an annual index. Each issue opens with a leader and closes with insight, a personal end-piece. In its three year history, arq has published work from all over the world: from Chile to Sweden and from Japan to the Netherlands - with a strong representation from the United Kingdom and United States. arq, like architecture itself, is all-embracing and written by and for both practitioners and academics. It provides an outlet for all those who wish to disseminate their work to an international audience.
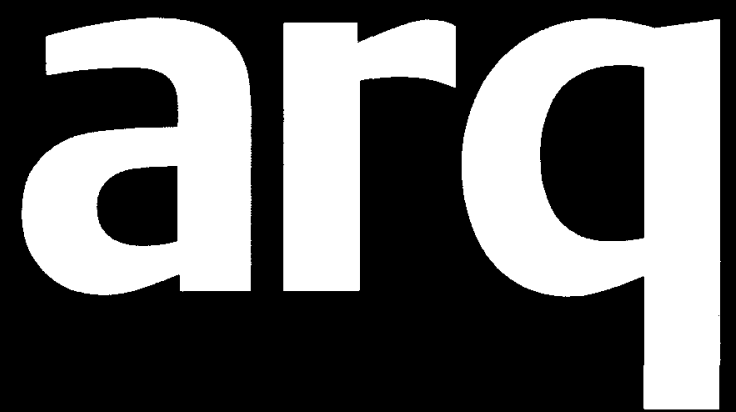

Please enter my subscription to arq: architectural research quarterly, volume 4,2000

$\square$ E76 (normally $\mathrm{f}_{95}$ ) institutions print only

E22 (normally E28) students

$\square$ E44 (normally $E_{55}$ ) individuals print only

EU residents only. VAT may be payable at your local rate if not registered.

Our vat registration number: $C B 214141614$ If registered, your VAT registration no:

Total subscription payment $E$ Eu residents only, if not registered add VAT at appropriate rate

Total $€$

Name

Address

\section{Payment enclosed}

Cheque in sterling (payable to Cambridge University Press)

$\square$ Bank Draft

$\square$ Post Office Giro (A/C no 5716055 GB Bootle - please send Credit Card-VISA I MasterCard I American Express (delete where applicable)

Card no

Expiry date

Signature

Photocopy this page and send your order to: Journals Customer Services, Cambridge University Press, Edinburgh Building, Shaftesbury Road.

Cambridge, CB2 $2 \mathrm{RU}$

$T+44(0) 1223326070$

$F+44(0) 1223315052$

E journals_subscriptions@cup.cam.ac.uk 